\title{
Effect of Lycopene on Peritoneal Fluid Malondialdehyde Level in Endometriosis
}

\author{
Nanang W. Astarto, Tono Djuwantono, Yelliantty \\ Departement of Obstetrics and Gynecology, Faculty of Medicine \\ Padjadjaran University, Hasan Sadikin Hospital \\ Jl. Pasteur No. 38 Bandung 40161 Indonesia \\ Email:nw_astarto@yahoo.com
}

\begin{abstract}
Oxidative stress is a factor that contribute in pathogenesis of endometriosis. This condition could also implicated in infertility. Lycopene is a carotenoid that has antioxidant activity. Supplementation of lycopene can reduce oxidative stress in peritoneal fluid of women with endometriosis. This study aims to compare the effect of lycopene on malondialdehyde (MDA) levels in peritoneal fluid of women with endometriosis. It is an experimental study on peritoneal fluid from five women with endometriosis. The result show that lycopene supplementation affecting the MDA levels in peritoneal fluid. MDA levels in peritoneal fluid with lycopene is lower than without lycopene. It conclude that lycopene is proved lowering MDA levels in peritoneal fluid of women with endometriosis.
\end{abstract}

Keywords: endometriosis lycopene, malondialdehyde 


\title{
Pengaruh Lycopene terhadap Kadar Malondialdehid dalam Zalir Peritoneum Pasien Endometriosis
}

\author{
Nanang W. Astarto, Tono Djuwantono, Yelliantty \\ Departemen Obstetri Ginekologi, Fakultas Kedokteran \\ Universitas Padjadjaran, Rumah Sakit Hasan Sadikin \\ Jl. Pasteur No. 38 Bandung 40161 Indonesia \\ Email:nw_astarto@yahoo.com
}

\begin{abstract}
Abstrak
Keberadaan stres oksidatif diduga menjadi salah satu mekanisme yang terlibat di dalam patofisiologi endometriosis. Keadaan ini juga menjadi penyebab kegagalan kehamilan dan infertilitas pada wanita endometriosis. Lycopene merupakan suatu karotenoid lipofilik yang bersifat antioksidan dan prooksidan. Penambahan antioksidan tersebut diharapkan dapat mengurangi tingkat stres oksidatif yang tinggi di dalam zalir peritoneum pasien endometriosis, sehingga motilitas, viabilitas dan integritas DNA sperma dapat terjaga baik. Penelitian ini bertujuan untuk menganalisis pengaruh pemberian lycopene terhadap kadar malondialdehid (MDA) pada cairan peritoneum pasien endometriosis. Metode penelitian ini adalah penelitian eksperimental dengan membandingkan pengaruh pemberian perlakuan lycopene terhadap cairan peritoneum dari lima pasien endometriosis. Hasil penelitian menunjukkan adanya pengaruh pemberian lycopene terhadap kadar MDA di dalam zalir peritoneum. Kadar MDA dalam zalir peritoneum yang diberi perlakuan lycopene lebih rendah dibandingkan zalir peritoneum yang tidak diberi perlakuan lycopene. Berdasarkan hal tersebut maka dapat disimpulkan bahwa pemberian lycopene terbukti dapat menurunkan kadar MDA di dalam zalir peritoneum pasien endometriosis.
\end{abstract}

Kata kunci: endometriosis, lycopene, malondialdehid 


\section{Research Article}

\section{Pendahuluan}

Endometriosis merupakan penyakit ginekologik progresif akibat adanya pertumbuhan jaringan mirip kelenjar dan stroma endometrium di luar rongga uterus. ${ }^{1-2}$ Endometriosis sebagian besar tumbuh pada peritoneum pelvis dan jaringan ekstrauterin lainnya. Lesi endometriosis akan berproliferasi dan menyusup pada jaringan sekitar, sehingga mengakibatkan pengerasan jaringan (fibrosis), perlekatan dan distorsi organ. Jaringan ektopik ini dapat tumbuh mandiri dan terkait dengan proses haid di endometrium. Keadaan ini menyebabkan adanya pemajanan oleh serpihan haid sehingga dapat mengakibatkan peradangan menahun. ${ }^{3}$ Peradangan menahun oleh endometriosis dapat mengakibatkan nyeri pelvik menahun, gangguan organ intraabdominal dan intrapelvik, serta menurunkan fertilitas. ${ }^{4-5}$ Keadaan ini disebabkan peluruhan tersebut yang menyerupai dan bersamaan dengan haid. Serpih yang dihasilkannya kemudian menyebabkan serangkaian proses peradangan lokal, perlekatan, dan nyeri. ${ }^{6-7}$

Kondisi zalir peritoneum dipengaruhi oleh keberadaan endometriosis. Ho $\mathrm{dkk}^{8}$ menemukan adanya perubahan volume dan fungsi beberapa komponen imunologis pada zalir peritoneum yang meliputi monosit-makrofag fagositik, sel Natural Killer (NK cells), limfosit T sitotoksik, sel B, atau mediator inflamasi seperti komplemen dan sitokin. Selain itu, zalir peritoneum pada wanita penderita endometriosis mengalami peningkatan konsentrasi dan aktivasi makrofag, konsentrasi sitokin tumor necrosis factor- $\alpha$ (TNF- $\alpha$ ), macrophage-derived growth factor, dan macrophage colony stimulating factor (M-CSF).

Perubahan komponen pada zalir peritoneal diduga berpengaruh terhadap keberhasilan proses fertilisasi. Menurut Perdichizzi $\mathrm{dkk}^{9}$, perubahan komponen zalir peritoneum pada penderita endometriosis dapat menurunkan kemampuan gerak dan meningkatkan kerusakan DNA pada sperma. Keadaan inilah yang dapat mengakibatkan proses fertilisasi alami terganggu dan berujung pada infertilitas.

Keberadaan stres oksidatif diduga menjadi salah satu mekanisme yang terlibat di dalam patofisiologi endometriosis. Stres oksidatif dapat membantu pertumbuhan dan perekatan sel endometrium di rongga peritoneal. Hal ini dibuktikan oleh adanya peningkatan kadar reactive oxygen species (ROS) di serum dan zalir peritoneal penderita endometriosis. ${ }^{10-12}$ Stres oksidatif terbukti juga dapat bersifat toksik terhadap sperma dengan merusak membran sel, menginduksi kerusakan DNA dan juga apoptosis pada sperma. Pemajanan ROS terhadap sperma yang berlebih dapat mengakibatkan akumulasi peroksidasi lipid membran yang mengakibatkan membran plasma kehilangan fluiditas dan integritasnya yang dibutuhkan pada kejadian fusi membran dalam fertilisasi. ${ }^{13-15}$ 
Kerusakan DNA sperma yang diakibatkan stres oksidatif dapat mengganggu integritas DNA yang dibutuhkan untuk mencapai dan mempertahankan perkembangan embrio normal. Kerusakan DNA yang terjadi dapat mengakibatkan apoptosis embrio, gangguan proses perkembangan, implantasi, bahkan dapat mengakibatkan kelainan pada janin. Keadaan ini juga menjadi penyebab kegagalan kehamilan dan infertilitas pada wanita endometriosis. ${ }^{16-17}$

Keberadaan stres oksidatif juga dapat memengaruhi motilitas sperma. Stres oksidatif dapat masuk ke dalam sitoplasma dan memengaruhi kerja mitokondria dalam metabolisme energi yang dibutuhkan untuk pergerakan. Selain itu, stres oksidatif juga dapat mengganggu polimerisasi dan depolimerisasi aktin miosin pada ekor yang selanjutnya dapat mengakibatkan gangguan pergerakan dari spermatozoa. ROS bersifat toksik terhadap sel manusia, tetapi secara normal juga dihasilkan oleh tubuh sebagai produk samping dari metabolisme oksigen. Beberapa jenis sel seperti leukosit dan spermatozoa juga memiliki mekanisme untuk menghasilkan ROS dengan tujuan tertentu. Umumnya sel dalam tubuh juga mengekspresikan gen penghasil protein yang penting dalam melindungi sel dari dampak buruk ROS sebagai upaya mempertahankan kelangsungan hidup. Oleh karena itu, gen pengekspresi antioksidan pada sel tubuh mencerminkan upaya penyeimbangan prooksidan/antioksidan yang dihasilkan lingkungan sel. ${ }^{18-}$ 19

Di alam terdapat berbagai macam sumber antioksidan, seperti buah dan sayuran. Beberapa senyawa antioksidan yang telah diketahui di antaranya adalah l-carnitine, lycopene, vitamin $\mathrm{C}$, dan beberapa senyawa polifenol lainnya. Di antara berbagai macam senyawa antioksidan, lycopene merupakan senyawa antioksidan yang dianggap paling kuat dalam mengimbangi kerja senyawa oksidatif. ${ }^{20-21}$

Lycopene merupakan suatu karotenoid lipofilik yang bersifat antioksidan dan prooksidan. Aktivitas antioksidan karotenoid umumnya bersifat katalitik dan efektif menangkap radikal bebas. Penelitian Srinivasan menunjukkan bahwa lycopene dapat melindungi lipid membran dan DNA hepatosit dari kerusakan yang disebabkan senyawa oksidatif secara in vitro. $^{22}$

Uraian di atas memunculkan gagasan untuk memanfaatkan lycopene untuk membantu kelangsungan hidup dan menjaga keadaan spermatozoa dalam proses fertilisasi pada penderita endometriosis. Penambahan antioksidan tersebut diharapkan dapat mengurangi tingkat stres oksidatif yang tinggi di dalam zalir peritoneum pasien endometriosis, sehingga motilitas, viabilitas dan integritas DNA sperma dapat terjaga baik. Upaya ini bertujuan untuk meningkatkan keberhasilan kehamilan dan mengurangi dampak negatif dari zalir peritoneum pasien endometriosis. 
Research Article

Pada penelitian ini ingin diketahui pengaruh lycopene terhadap penurunan kadar malondialdehid (MDA) zalir peritoneum pasien endometriosis.

\section{Metode}

Penelitian ini menggunakan sampel zalir peritoneum yang berasal dari pasien endometriosis dengan grade I-II. Pengambilan zalir peritoneum cavum Douglas dilakukan oleh dokter spesialis Obstetri dan Ginekologi saat melakukan laparoskopi diagnostik/operatif atau laparatomi sebanyak kurang lebih $10 \mathrm{~mL}$. Zalir peritoneum kemudian diproses dengan cara disentrifugasi $1500 \mathrm{rpm}$ selama 10 menit, kemudian difiltrasi dengan menggunakan membran 0,22 $\mu \mathrm{M}$ (Sartorius Stedim ${ }^{\circledR}$, Biotech, Denmark). Supernatan yang dihasilkan dari proses tersebut disimpan di pendingin dengan suhu $-70^{\circ} \mathrm{C}$ hingga jumlah sampel terpenuhi $(n=5)$.

Zalir peritoneum tersebut kemudian diberi perlakuan senyawa antioksidan tunggal dengan beberapa konsentrasi. Antioksidan yang diberikan adalah Lycopene (SIGMA) dengan menggunakan beberapa konsentrasi yaitu 50, 25, 12,5, 6,25 ( $\mu \mathrm{M})$. Setelah diberi Lycopene, zalir peritoneum kemudian diinkubasi selama 30 menit, kemudian dilakukan pengukuran MDA dengan menggunakan kit BIOXYTECH® MDA-586 ${ }^{\mathrm{TM}}$.

\section{Hasil}

Pengaruh pemberian lycopene terhadap kadar MDA dalam zalir peritoneum pasien endometriosis ditampilkan pada gambar di bawah ini.

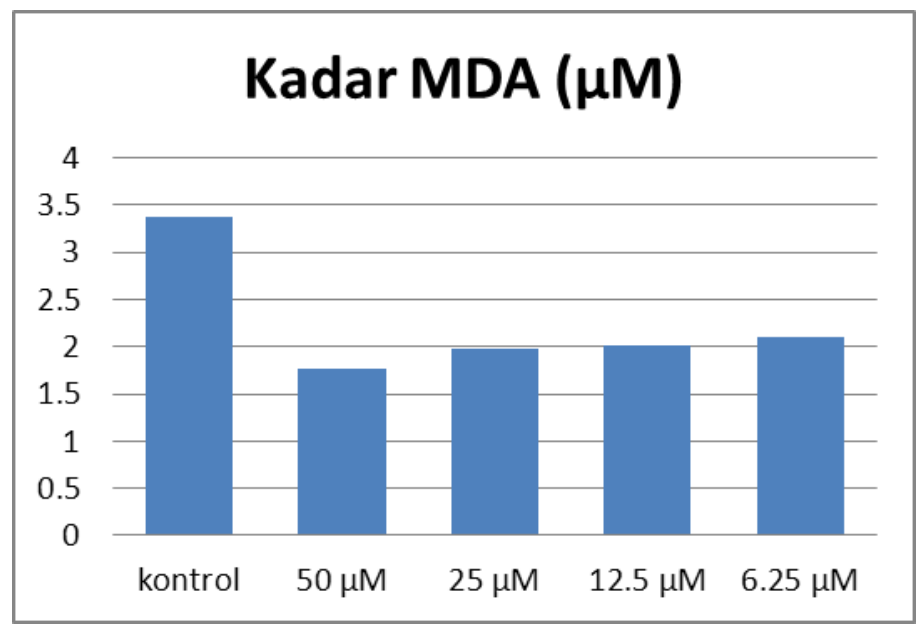

Gambar Pengaruh Pemberian Lycopene terhadap Kadar MDA dalam Zalir Peritoneum Pasien Endometriosis 
Research Article

\section{Diskusi}

Hasil penelitian menunjukkan adanya pengaruh pemberian lycopene terhadap kadar MDA di dalam zalir peritoneum. Kadar MDA dalam zalir peritoneum yang diberi perlakuan lycopene lebih rendah dibandingkan zalir peritoneum yang tidak diberi perlakuan lycopene/kontrol. Hasil tersebut menunjukkan bahwa pemberian lycopene terbukti dapat menurunkan kadar MDA di dalam zalir peritoneumHasil penelitian juga menunjukkan adanya pengaruh konsentrasi pemberian lycopene terhadap penurunan kadar MDA di zalir peritoneum pasien endometriosis. Semakin tinggi konsentrasi lycopene yang diberikan semakin besar pula penurunan kadar MDA yang dihasilkan. Hal tersebut menunjukkan bahwa semakin banyak lycopene yang diberikan semakin banyak pula radikal bebas atau stres oksidatif yang terikat. Selain itu, hasil tersebut juga menunjukkan bahwa masih diperlukannya penelitian lanjutan mengenai kadar pemberian lycopene yang efektif dan efisien jika diaplikasikan secara in vivo.

Penurunan kadar MDA karena pemberian lycopene telah dibuktikan oleh beberapa penelitian sebelumnya. Salah satunya adalah penelitian yang dilakukan oleh Sarkar dkk ${ }^{23}$, yaitu melihat pengaruh suplemen lycopene yang diberikan per oral kepada individu selama 10 minggu terhadap kadar stres oksidatif. Hasil penelitian tersebut menunjukkan adanya penurunan kadar MDA yang signifikan pasca pemberian lycopene selama 10 minggu dibandingkan dengan kadar sebelum perlakuan.

Penurunan kadar MDA yang diakibatkan pemberian lycopene menunjukkan bahwa antioksidan lycopene dapat bekerja secara langsung untuk menekan radikal bebas dalam zalir peritoneum pasien endometriosis. Hal ini dapat menjadi dasar metode pengaplikasian lycopene secara langsung kepada pasien. Beberapa aplikasi lycopene yang memungkinkan diantaranya adalah penggunaan lycopene sebagai suplemen atau komposisi tambahan untuk terapi pasca operasi endometriosis atau bahkan terapi untuk endometriosis ringan. Aplikasi tersebut diharapkan dapat menekan radikal bebas atau stres oksidatif di zalir peritoneum endometriosis, membantu sistem imun dalam memperbaiki kondisi endometriosis dan metabolisme pada tingkat selular dan jaringan berlangsung dengan lebih baik sehingga memperbaiki dan menekan progresivitas juga risiko rekurensi. Oleh karena itu perlu dilakukan penelitian lanjutan mengenai perbandingan efektivitas dan efisiensi metode pemberian lycopene terhadap pasien endometriosis, terutama yang akan melakukan program teknologi reproduksi berbantu.

\section{Simpulan}

Lycopene menurunkan kadar MDA di dalam zalir peritoneum pasien endometriosis. 


\section{Research Article}

\section{Daftar Pustaka}

1. Clinical gynecologic endocrinology \& infertility.Edisi ke-8. Fritz MA, Speroff L, penyunting. Philadelpia: Lippincott Williams \& Wilkins; 2011.

2. Practice bulletin no. 114: management of endometriosis. Obstet Gynecol. 2010;116(1):223-36.

3. Agarwal N, Subramanian A. Endometriosis - morphology, clinical presentations and molecular pathology. J Lab Physicians. 2010;2(1):1-9.

4. Halme J, Hammond MG, Hulka JF, Raj SG, Talbert LM. Retrograde menstruation in healthy women and in patients with endometriosis. Obstet Gynecol. 1984;64:151-4.

5. Vercellini P, Giorgi De, Aimi G, Panazza S, Uglietti A, Crisignani PG. Menstrual characteristics in women with and without endometriosis. Obstet Gynecol. 1997;90:264-8.

6. Barrier BF. Immunology of endometriosis. Clin Obstet Gynecol. 2010;53(2):397-402.

7. Momoeda M, Taketani Y, Terakawa N, Hoshiai H, Tanaka K, Tsutsumi O, et al. Is endometriosis really associated with pain? Gynecol Obstet Invest. 2002;54 Suppl 1:18-21; discussion -3.

8. Ho HN, Wu MY, Yang YS. Peritoneal cellular immunity and endometriosis. Am J Reprod Immunol. 1997;38(6):400-12.

9. Perdichizzi A, Nicoletti F, La Vignera S, Barone N, D'Agata R, Vicari E, et al. Effects of tumour necrosis factoralpha on human sperm motility and apoptosis. J Clin Immunol. 2007;27(2):152-62.

10. Agarwal A, Gupta S, Sharma R. Oxidative stress and its implications in female infertility - a clinician's perspective. Reprod Biomed Online. 2005;11(5):641-50.

11. Gupta S, Goldberg JM, Aziz N, Goldberg E, Krajcir N, Agarwal A. Pathogenic mechanisms in endometriosisassociated infertility. Fertil Steril. 2008;90(2):247-57.

12. Matsuzaki S, Schubert B. Oxidative stress status in normal ovarian cortex surrounding ovarian endometriosis. Fertil Steril. 2010;93(7):2431-2.

13. Agarwal A, Makker K, Sharma R. Clinical relevance of oxidative stress in male factor infertility: an update. Am J Reprod Immunol. 2008;59(1):2-11.

14. Kefer JC, Agarwal A, Sabanegh E. Role of antioxidants in the treatment of male infertility. Int J Urol. 2009;16(5):449-57.

15. Saleh RA, Agarwal A. Oxidative stress and male infertility: from research bench to clinical practice. J Androl. 2002;23(6):737-52.

16. Mahfouz R, Sharma R, Thiyagarajan A, Kale V, Gupta S, Sabanegh E, dkk. Semen characteristics and sperm DNA fragmentation in infertile men with low and high levels of seminal reactive oxygen species. Fertil Steril. 2010;94(6):2141-6.

17. Mahfouz RZ, du Plessis SS, Aziz N, Sharma R, Sabanegh E, Agarwal A. Sperm viability, apoptosis, and intracellular reactive oxygen species levels in human spermatozoa before and after induction of oxidative stress. Fertil Steril. 2010;93(3):814-21.

18. Makker K, Agarwal A, Sharma R. Oxidative stress \& male infertility. Indian J Med Res. 2009;129(4):357-67.

19. Pasqualotto FF, Sharma RK, Kobayashi H, Nelson DR, Thomas AJ, Jr., Agarwal A. Oxidative stress in normospermic men undergoing infertility evaluation. J Androl. 2001;22(2):316-22.

20. Story EN, Kopec RE, Schwartz SJ, Harris GK. An update on the health effects of tomato lycopene. Annu Rev Food Sci Technol. 2010;1:189-210.

21. Kelkel M, Schumacher M, Dicato M, Diederich M. Antioxidant and anti-proliferative properties of lycopene. Free Radic Res. 2011;45(8):925-40.

22. Srinivasan M, Sudheer AR, Pillai KR, Kumar PR, Sudhakaran PR, Menon VP. Lycopene as a natural protector against gamma-radiation induced DNA damage, lipid peroxidation and antioxidant status in primary culture of isolated rat hepatocytes in vitro. Biochim Biophys Acta. 2007;1770(4):659-65.

23. Sarkar PD, Gupta T, Sahu A. Comparative analysis of lycopene in oxydative stress. JAPI. 2012;60:17-9. 